\title{
SISTEM PENUNJANG KEPUTUSAN PEMBELIAN SEMBAKO TERPOPULER SAAT PANDEMI COVID-19 PADA TOKO ALFAMINI
}

\author{
Adam Shifaurrohman ${ }^{1}$, Rayung Wulan ${ }^{2}$, Sigit Indra Prianto ${ }^{3}$ \\ ${ }^{1,2,3}$ Program Studi Teknik Informatika, Fakultas Teknik dan Ilmu Komputer, \\ Universitas Indraprasta PGRI \\ Jalan Raya Tengah No 80, Kelurahan Gedong, Pasar Rebo, Jakarta Timur \\ adamshifaurrohman@gmail.com ${ }^{1}$, utha2578@gmail.com², $\underline{\text { sigitsoebroto@gmail.com }}$
}

\begin{abstract}
Abstrak
Merebaknya pandemi Covid-19 menyebabkan kecemasan masyarakat di seluruh dunia. Kecemasan tersebut terjadi tidak hanya karena penularan virus, melainkan juga kecemasan akan pemenuhan kebutuhan pokok masyarakat. Penelitian ini bertujuan untuk membuatkan aplikasi program transaksi penjualan dan perangkingan hasil pemilihan customer menggunakan bahasa pemograman Java Netbeans dan database MySQL dalam perancangan sistemnya. Metode penelitian yang digunakan oleh peneliti adalah metode Weighted Product. Metode Weighted Product adalah suatu metode yang menggunakan perkalian untuk menghubungkan rating atribut, dimana rating setiap atribut harus dipangkatkan dulu dengan bobot yang bersangkutan. Tujuan pembuatan aplikasi ini yaitu membuat sistem penjualan yang terkomputerisasi dan menambahkan sistem penunjang keputusan. Maka dirumuskan permasalahan yang akan diselesaikan melalui aplikasi ini, yaitu bagaimana membuat sistem penjualan dan sistem penunjang keputusan untuk menentukan barang yang akan dibeli customer berdasarkan nilai yang mereka berikan kepada setiap barangnya. Adapun metode pengumpulan data yang peneliti pakai adalah metode observasi, studi literatur dan wawancara. Hasil yang didapat memberikan pengelolaan transaksi penjualan yang terkomputerisasi dan adanya sistem penunjang keputusan.
\end{abstract}

Kata Kunci : Sistem Penunjang Keputusan, Weighted Product, Sembako Terpopuler

\begin{abstract}
The outbreak of the Covid-19 pandemic has caused public anxiety around the world. This anxiety occurs not only because of the transmission of the virus, but also anxiety about meeting the basic needs of the community. This study aims to develop an application program for sales transactions and ranking the results of customer selection using the Java Netbeans programming language and MySQL database in system design. The research method used by the researcher is the Weighted Product method. The Weighted Product method is a method that uses multiplication to connect attribute ratings, where the rating of each attribute must first be raised to the power of the corresponding weight. The purpose of making this application is to create a computerized sales system and add a decision support system. Then the problems that will be solved through this application are formulated, namely how to make a sales system and a decision support system to determine the goods that the customer will buy based on the value they give to each item. The data collection methods that the author uses are observation methods, literature studies and interviews. The results obtained provide a computerized management of sales transactions and the existence of a decision support system.
\end{abstract}

Keyword : Decision Support System, Weighted Product, Most Popular Groceries

\section{PENDAHULUAN}

Pasca diumumkan bahwa terdapat dua orang warga Indonesia yang terjangkit Covid-19 pada bulan Maret 2020, masyarakat mulai melakukan aksi borong kebutuhan pokok, obat-obatan dan alat pelindung diri lainnya. Meskipun pemerintah telah menjamin ketersediaan bahan pangan yang cukup, hal ini tetap membuat masyarakat merasa cemas [1]. Sistem Pendukung keputusan (SPK) adalah suatu proses pemikiran dalam rangka pemecahan masalah untuk memperoleh hasil akhir untuk dilaksanakan [2]. Sistem adalah suatu jaringan kerja dari prosedur-prosedur yang saling berhubungan, berkumpul bersama-sama untuk melakukan kegiatan atau untuk melakukan sasaran yang tertentu [3]. Pada toko Alfa Mini pendataan barang masih dilakukan dengan cara manual lalu 
belum terdapat sistem penjualan dan sistem penunjang keputusan. Ada 4 tahap dalam pengambilan keputusan yaitu penelusuran, perancangan, pemilihan dan implementasi [4]. Untuk itu diperlukannya sistem penjualan dan sistem penunjang keputusan sehingga nantinya dapat membantu pemilik toko dalam pendataan barang dan membantu customer dalam pemilihan barang yang sesuai dengan kebutuhan mereka. Dalam membuat aplikasi ini, peneliti menggunakan metode Weight Product (WP). Sistem pendukung keputusan membantu pengambil keputusan untuk memecahkan masalah, terutama dalam berbagai isu yang sangat kompleks dan tidak terstruktur [5]. Hasil penelitian menyebutkan dengan adanya sistem penjualan dapat meminimalisir adanya kesalahan data dan perhitungan penjualan, customer juga terbantu dengan adanya sistem penunjang keputusan karena dapat memberikan saran pengambilan barang sesuai yang dibutuhkan.

\section{PENELITIAN RELEVAN}

Dalam rangka mendapatkan hasil penelitian yang baik, selain melakukan penelitian secara langsung penelitian juga berdasarkan kajian pustaka, dari penelitian yang telah dilakukan sebelumnya, beberapa hasil penelitian yang menjadi acuan antara lain adalah:

1. Petricia Oktavia Staff Pengajar Fakultas Teknik Program Studi Teknik Informatika Universitas Pamulang, Banten menulis artikel yang berjudul "Sistem Pendukung Keputusan Seleksi Penerimaan Beasiswa Dengan Metode Weighted Product Pada SMP Negeri 1 Parung Berbasis Web" berdasarkan hasil penilaian pemberian beasiswa bisa dilakukan dengan lebih cepat dan tepat.

2. Martine Mahasiswa Program Studi Sistem Informasi Sekolah Tinggi Manajemen Informatika dan Komputer (STMIK) GICI Batam menulis skripsi yang berjudul "Penerapan Metode Weighted Product (WP) Dalam Sistem Penunjang Keputusan Pemilihan Laptop Berdasarkan Kebutuhan Spesifikasi Calon Pembeli Berbasis Website" berhasil memberikan saran pemilihan laptop yang merupakan nilai tertinggi dari perhitungan metode Weigted Product.

\section{METODE PENELITIAN}

Metode penelitian yang dilakukan oleh penulis dalam membuat aplikasi sistem penunjang keputusan pembelian sembako adalah metode Weighted Product (WP) merupakan metode pengambilan keputusan dengan cara perkalian untuk menghubungkan rating atribut, dimana rating setiap atribut harus dipangkatkan dulu dengan bobot atribut yang bersangkutan untuk mendapatkan hasilnya [6]. Berikut rumus metode Weighted Product:

Perbaikan bobot untuk $\Sigma \mathrm{Wj}=1$ adalah dengan menggunakan rumus:

$$
\mathrm{W}_{\mathrm{j}}=\frac{w}{\sum w}
$$

Variabel W adalah pangkat bernilai positif untuk atribut keuntungan dan bernilai negatif untuk atribut biaya. Preferensi untuk alternatif Si diberikan sebagai berikut:

$$
\mathrm{S}_{\mathrm{i}}=\prod_{j}^{n} x_{i_{j}}^{w_{j}}
$$

Dengan $i=1,2, \ldots, n$ dan $\mathrm{j}$ sebagai atribut $=1,2, \ldots, n$.

Keterangan:

$\Pi$ : product.

$\mathrm{Si}:$ skor / nilai dari setiap alternatif.

$\mathrm{Xij}$ : nilai alternatif ke- $\mathrm{i}$ terhadap atribut ke- $\mathrm{j}$

$\mathrm{wj}=$ bobot dari setiap atribut atau kriteria

$\mathrm{n}$ : Banyaknya kriteria 
Untuk mencari alternatif terbaik dilakukan dengan persamaan berikut:

$\mathrm{V}_{\mathrm{i}}=\frac{S i}{\prod_{j=1}^{n}\left(x_{j}^{*}\right)^{w} j}$

Di mana :

$\mathrm{V}$ : Preferensi alternatif dianalogikan sebagai vektor V

$X$ : Nilai Kriteria

W : Bobot kriteria/subkriteria

i : Alternatif

$\mathrm{j}:$ Kriteria

$\mathrm{n}$ : Banyaknya kriteria

Kelebihan metode WP yaitu mempermudah user untuk memberikan pembobotan terhadap kriteria yang memiliki nilai yang hampir sama, dapat digunakan untuk pengambilan keputusan single dan keputusan multidimensional, dan dapat menyelesaikan pengambilan keputusan secara praktis, karena konsepnya sederhana dan mudah dipahami. Kelemahan metode WP yaitu tidak banyak user yang menggunakan metode ini dalam pengambilan keputusan dan Metode ini hanya metode matematis tanpa ada pengujian secara statistik sehingga tidak ada batas kepercayaan dari kebenaran model yang terbentuk. Ada 4 fase dalam proses pengambilan keputusan yaitu intelligence, design, choice dan implementation [7]. Berikut gambar alurnya:

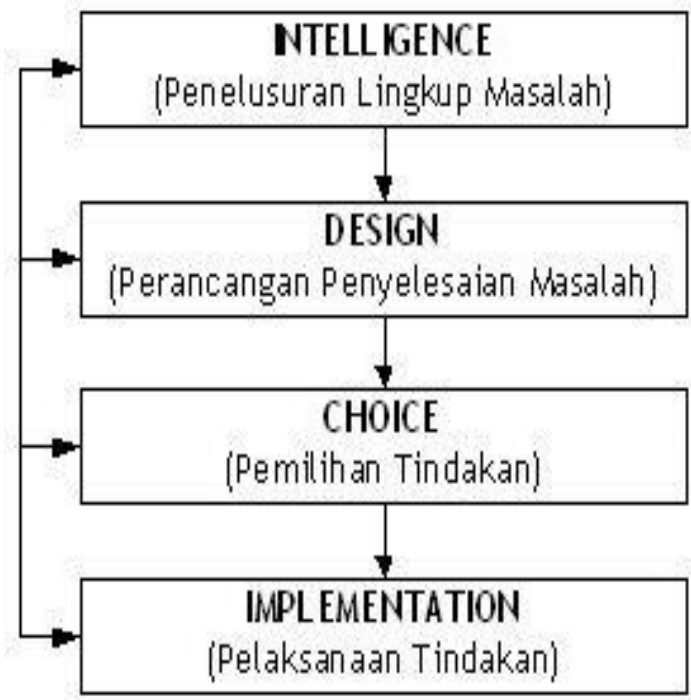

Gambar 1. Alur Pengambilan Keputusan

Metode WP cukup banyak digunakan untuk pengambilan keputusan karena metodenya yang sederhana dengan memasukkan semua faktor dan komputasinya cepat [8] serta mampu memilih alternatif terbaik dari sejumlah alternatif [9]. Metode WP ini lebih efisien karena waktu yang dibutuhkan dalam perhitungan lebih singkat [10].

\section{HASIL DAN PEMBAHASAN}

Hasil penelitian ini didapatkan sembako terpopuler saat pandemi covid-19 menggunakan metode weighted product. Berikut penjelasan perhitungannya: 


\section{Kriteria dan Bobot}

Dalam penelitian ini terdapat kriteria dan bobot yang dibutuhkan untuk menentukan pemilihan sembako yang akan dibeli oleh customer. Adapun kriterianya adalah:

Tabel 1. Data Barang

\begin{tabular}{|c|l|c|c|c|c|}
\hline \multirow{2}{*}{ No } & \multirow{2}{*}{ Nama Alternatif } & \multicolumn{4}{|c|}{ Nilai } \\
\cline { 3 - 6 } & & C1 & C2 & C3 & C4 \\
\hline 1 & Poky & 500 & 7 & 8 & 9 \\
\hline 2 & Shampo & 1000 & 5 & 6 & 7 \\
\hline 3 & Gula Pasir & 18000 & 6 & 7 & 6 \\
\hline 4 & Minyak & 6000 & 8 & 7 & 6 \\
\hline 5 & Tango & 2000 & 7 & 8 & 6 \\
\hline
\end{tabular}

Tabel 1 berisi tentang data sembako dan nilai yang diberikan oleh customer yang di proses menggunakan metode WP.

Tabel 2. Kriteria

\begin{tabular}{|c|l|}
\hline Kriteria & \multicolumn{1}{|c|}{ Keterangan } \\
\hline $\mathrm{C} 1$ & Harga \\
\hline $\mathrm{C} 2$ & Kandungan Gizi \\
\hline $\mathrm{C} 3$ & Vitamin \\
\hline $\mathrm{C} 4$ & Kemasan \\
\hline
\end{tabular}

Tabel 2 mendefinisikan kriteria-kriteria yang akan dijadikan sebagai tolak ukur penyelesaian masalah.

Tabel 3. Nilai Bobot Kriteria

\begin{tabular}{|c|l|}
\hline Bobot & \multicolumn{1}{|c|}{ Keterangan } \\
\hline 5 & Sangat Baik \\
\hline 4 & Baik \\
\hline 3 & Cukup \\
\hline 2 & Rendah \\
\hline 1 & Sangat Rendah \\
\hline
\end{tabular}

Tabel 3 berisi nilai bobot pada kriteria untuk dijadikan acuan dalam perhitungan data.

\section{Perhitungan Metode WP}

Tabel 4. Alternatif Kriteria

\begin{tabular}{|c|l|c|}
\hline Kriteria & \multicolumn{1}{|c|}{ Keterangan } & Bobot \\
\hline C1 & Harga & 5 \\
\hline C2 & Kandungan Gizi & 4 \\
\hline C3 & Vitamin & 4 \\
\hline C4 & Kemasan & 3 \\
\hline \multicolumn{2}{|c|}{ Total } & 16 \\
\hline
\end{tabular}

Tahapan perhitungan menggunakan metode weighted product:

a. Melakukan normalisasi bobot menggunakan rumus (1)

$$
\begin{aligned}
& \mathrm{W} 1=\frac{5}{5+4+4+3}=0,3125 \\
& \mathrm{~W} 2=\frac{4}{5+4+4+3}=0,25 \\
& \mathrm{~W} 3=\frac{4}{4}=0,25
\end{aligned}
$$




$$
\mathrm{W} 4=\frac{\frac{3}{5+4+4+3}}{5+4+4+3}=0,1875
$$

b. Menghitung nilai vektor $\mathrm{S}$ menggunakan rumus (2)

$$
\begin{aligned}
& \mathrm{S} 1=\left(500^{\wedge}-0,3125\right) \times\left(7^{\wedge} 0,25\right) \times\left(8^{\wedge} 0,25\right) \times\left(9^{\wedge}-0,1875\right)=0,259835454 \\
& \mathrm{~S} 2=\left(1000^{\wedge}-0,3125\right) \times\left(5^{\wedge} 0,25\right) \times\left(6^{\wedge} 0,25\right) \times\left(7^{\wedge}-0,1875\right)=0,187639571 \\
& \mathrm{~S} 3=\left(18000^{\wedge}-0,3125\right) \times\left(6^{\wedge} 0,25\right) \times\left(7^{\wedge} 0,25\right) \times\left(6^{\wedge}-0,1875\right)=0,085140521 \\
& \mathrm{~S} 4=\left(7000^{\wedge}-0,3125\right) \times\left(8^{\wedge} 0,25\right) \times\left(7^{\wedge} 0,25\right) \times\left(6^{\wedge}-0,1875\right)=0,122899611 \\
& \mathrm{~S} 5=\left(2000^{\wedge}-0,3125\right) \times\left(7^{\wedge} 0,25\right) \times\left(8^{\wedge} 0,25\right) \times\left(6^{\wedge}-0,1875\right)=0,181790747
\end{aligned}
$$

c. Menghitung nilai vektor $\mathrm{V}$ menggunakan rumus (3)

$$
\begin{aligned}
& \mathrm{V} 1=\frac{0,259835454}{0,259835454+0,187639571+0,085140521+0,122899611+0,181790747}=0,310323208 \\
& \mathrm{~V} 2=\frac{0,187639571}{0,259835454+0,187639571+0,085140521+0,122899611+0,181790747}=0,224099185 \\
& \mathrm{~V} 3=\frac{0,085140521}{0,259835454+0,187639571+0,085140521+0,122899611+0,181790747}=0,10168389 \\
& \mathrm{~V} 4=\frac{0,122899611}{0,259835454+0,187639571+0,085140521+0,122899611+0,181790747}=0,146779822 \\
& \mathrm{~V} 5=\frac{0,181790747}{0,259835454+0,187639571+0,085140521+0,122899611+0,181790747}=0,217113896
\end{aligned}
$$

d. Rangking dari metode Weight Product

Tabel 5. Hasil Perangkingan

\begin{tabular}{|c|l|l|c|}
\hline No & \multicolumn{1}{|c|}{ Nama Alternatif } & Nilai & Rangking \\
\hline 1 & Poky & 0,310323208 & 1 \\
\hline 2 & Shampo & 0,224099185 & 2 \\
\hline 3 & Tango & 0,217113896 & 3 \\
\hline 4 & Minyak & 0,146779822 & 4 \\
\hline 5 & Gula Pasir & 0,10168389 & 5 \\
\hline
\end{tabular}

\section{Analisa Input}

Dalam metode penelitian ini kriteria yang digunakan dalam perangkingan yaitu berdasarkan harga, kandungan gizi, vitamin, dan kemasan. Lalu untuk sistem penjualannya yaitu mencetak struk penjualan berdasarkan tiap transaksi.

\section{Analisa Output}

Dalam metode penelitian ini hasil perangkingan diambil dari perkalian untuk menghubungkan kriteria, dimana kriteria setiap barang harus dipangkatkan terlebih dahulu dengan bobot. Lalu untuk sistem penjualannya setiap struk dicetak dalam bentuk pdf.

\section{Analisa Uji Coba}

Dibawah ini adalah tampilan hasil dari aplikasi sistem penjualan dan hasil perangkingan pada toko Alfa Mini. 


\section{Tampilan Layar}

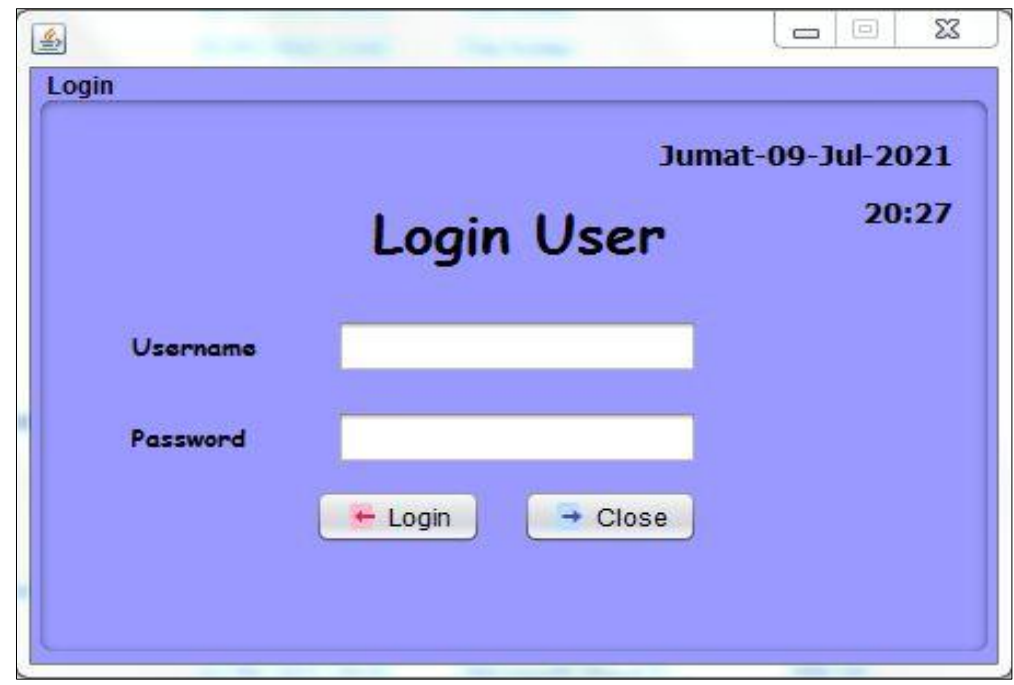

Gambar 2. Tampilan Layar Login

Tampilan ini terdapat pada saat awal aplikasi dijalankan. Menu login menggunakan kata kunci sebelum pengguna menggunakan aplikasi. Akses pada aplikasi ini diberikan kepada manajer keuangan dan pemilik toko. Tidak sembarangan orang dapat mengakses aplikasi ini. Hal ini dimaksudkan agar sistem dan data terjaga dengan baik dan aman.

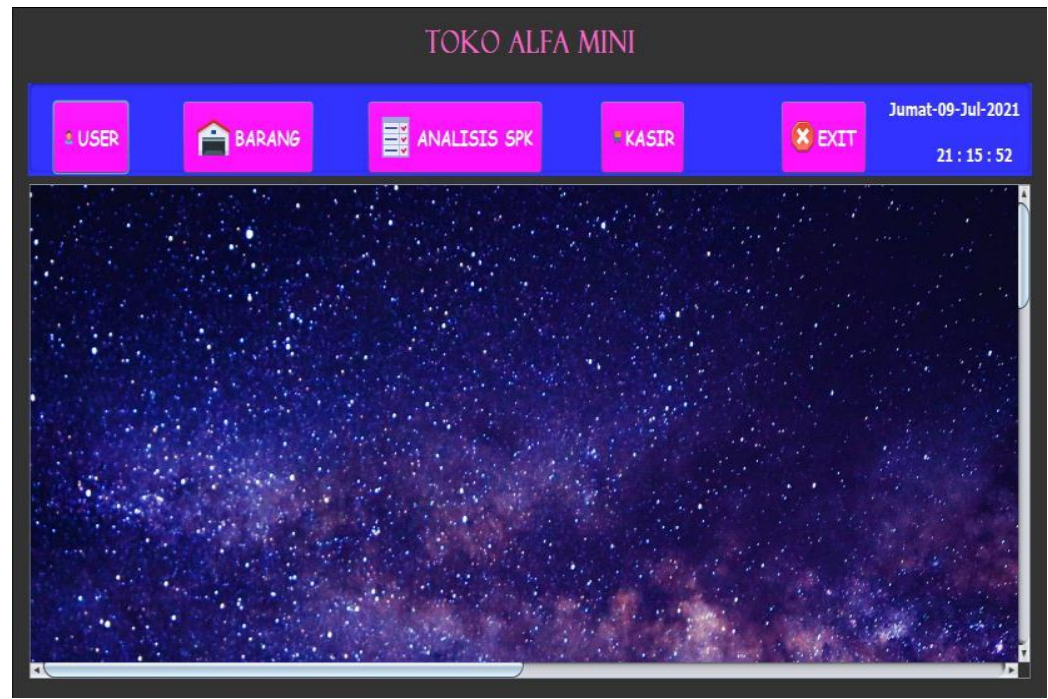

Gambar 3. Tampilan Layar Menu Utama

Tampilan layar diatas adalah tampilan menu utama. Terdapat 5 menu bar yang terdiri dari user, barang, analisis spk, kasir dan exit. 


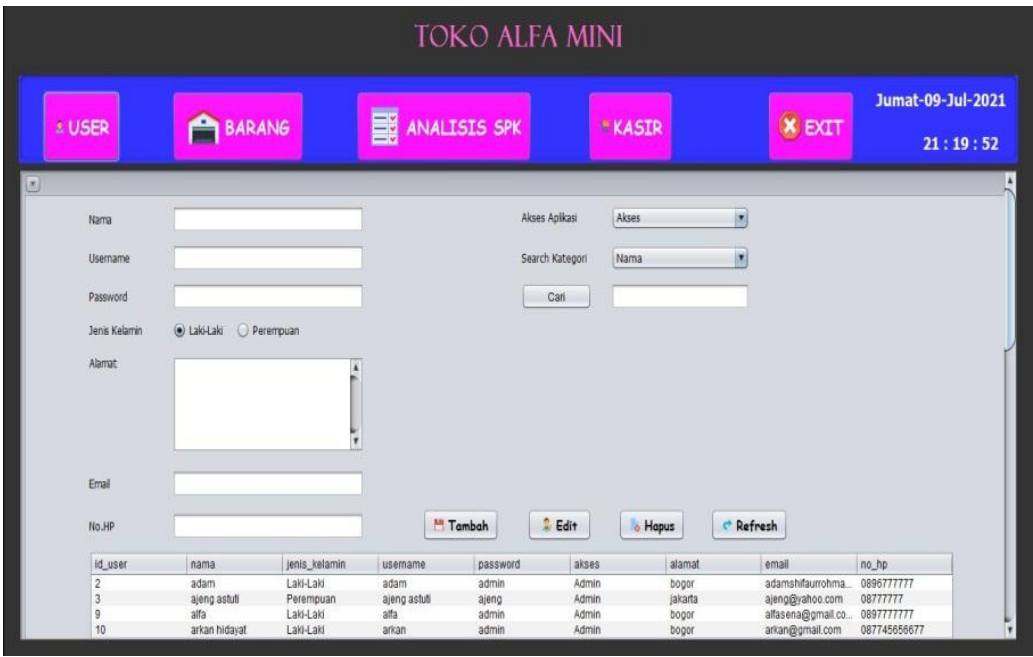

Gambar 4. Tampilan Layar Menu User

Tampilan layar diatas adalah tampilan menu user yang digunakan untuk menginput data user beserta kata kunci yang digunakan untuk mengakses ke menu utama dari menu login.

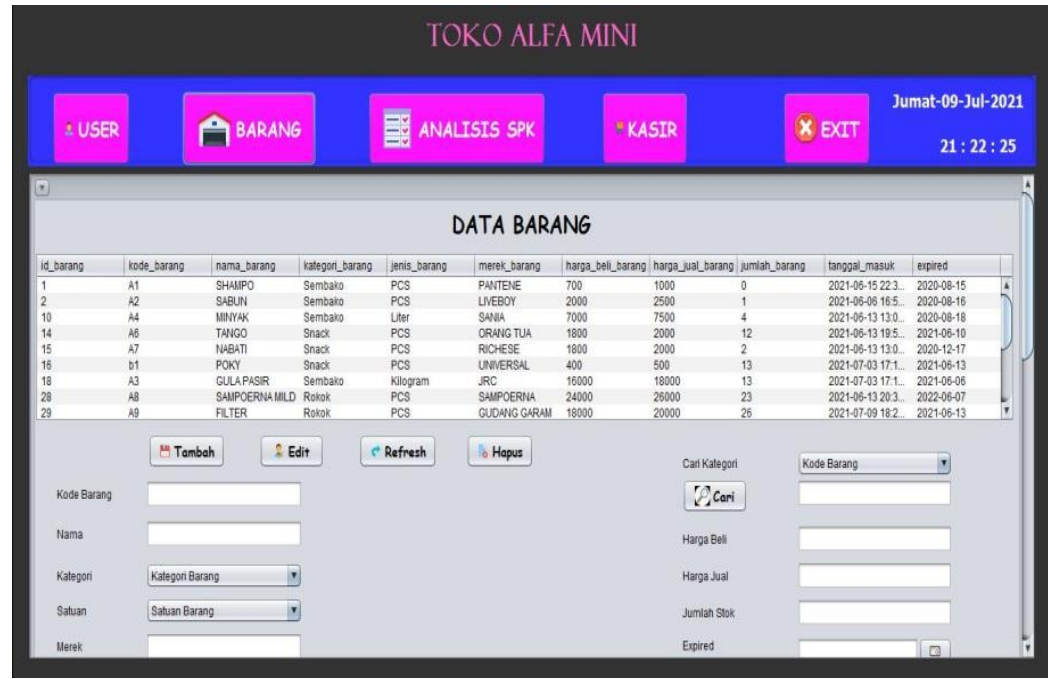

Gambar 5. Tampilan Layar Menu Barang

Tampilan layar diatas adalah tampilan menu barang yang digunakan untuk menginput data barang dan untuk pengecekan stok persediaan barang.

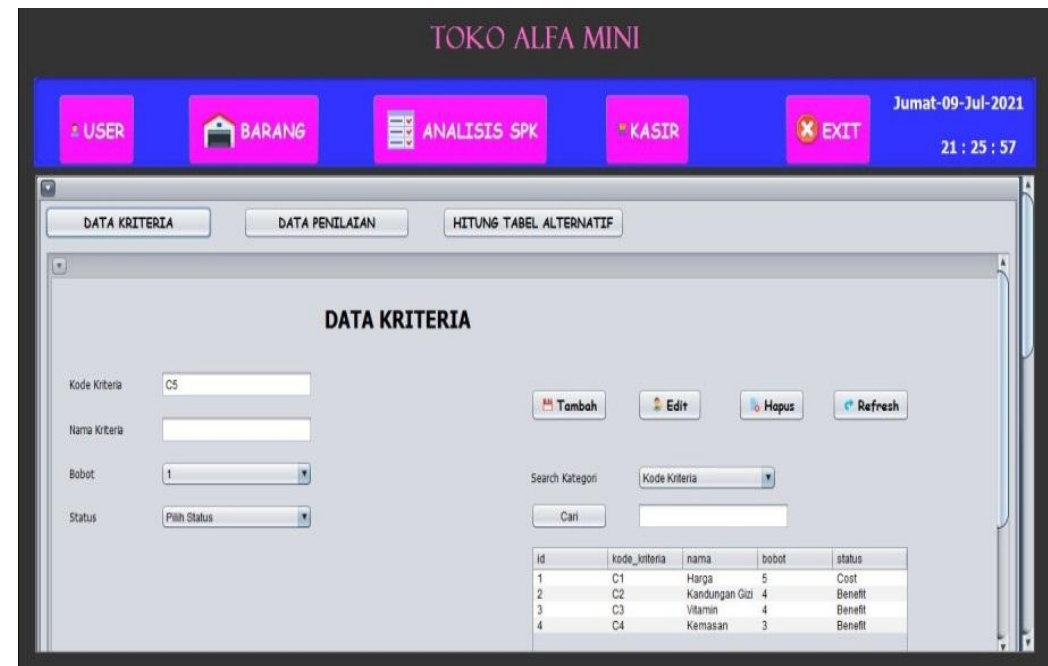

Gambar 6. Tampilan Layar Menu Data Kriteria 
Tampilan layar diatas adalah tampilan data kriteria yang digunakan untuk menginput data kriteria yang terdiri dari nama kriteria, bobot dan status.

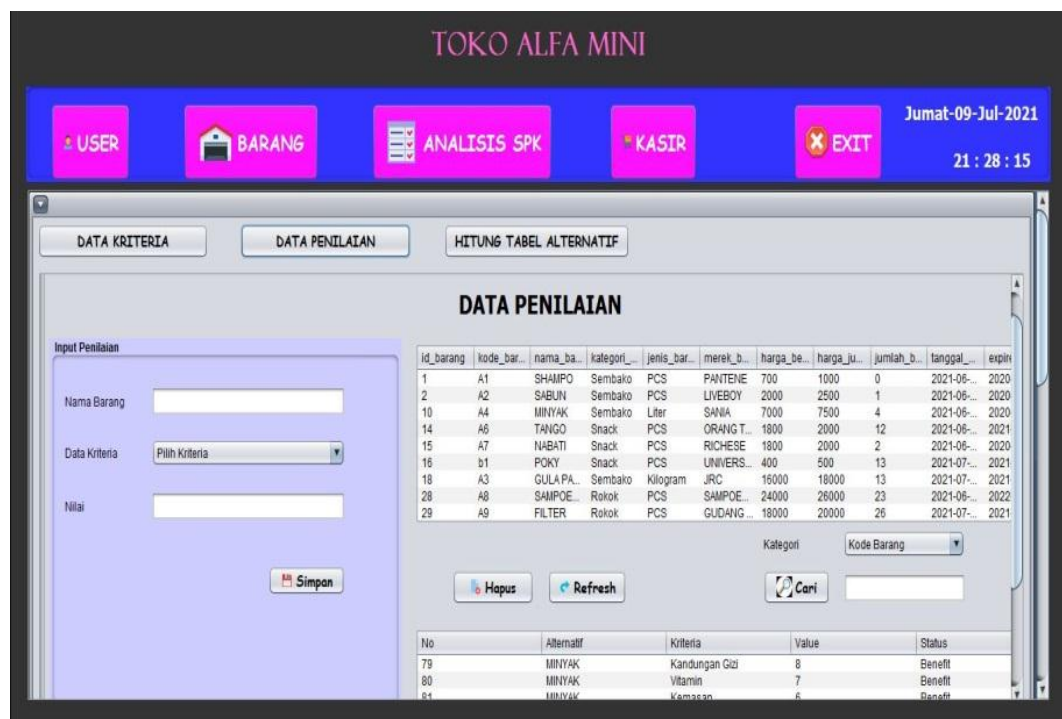

Gambar 7. Tampilan Layar Menu Data Penilaian

Tampilan layar diatas adalah tampilan data penilaian yang digunakan untuk memberikan nilai dari sebuah barang berdasarkan pilihan setiap kriteria.

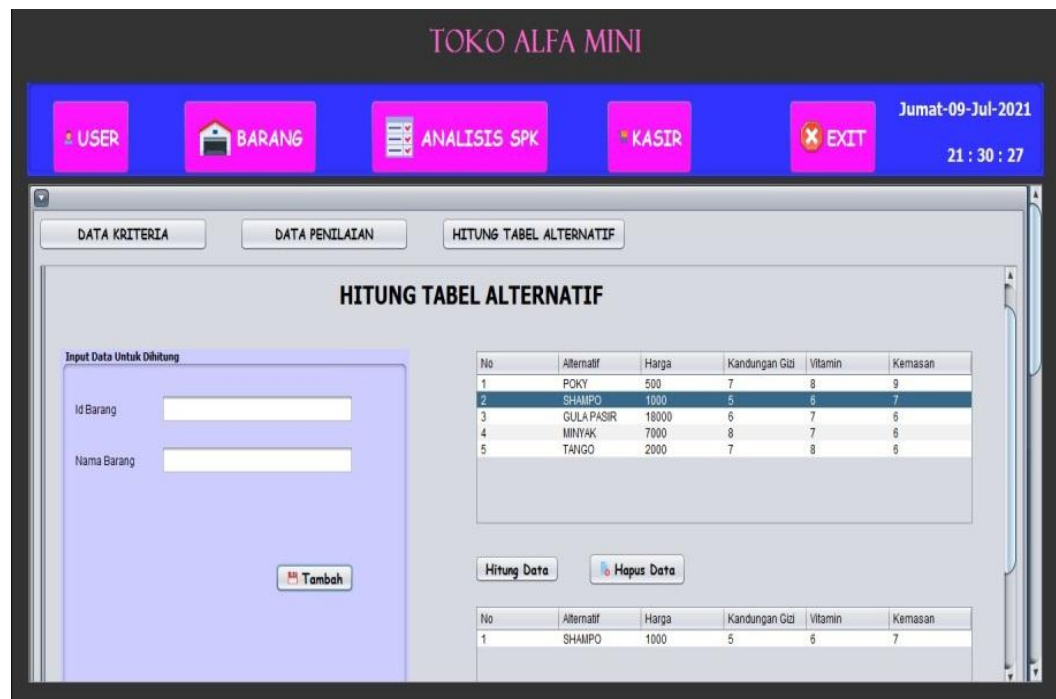

Gambar 8. Tampilan Layar Menu Hitung Tabel Alternatif

Tampilan layar diatas adalah tampilan hitung tabel alternatif yang digunakan untuk perhitungan SPK yang nantinya akan muncul perangkingan dari barang yang sudah dihitung. 


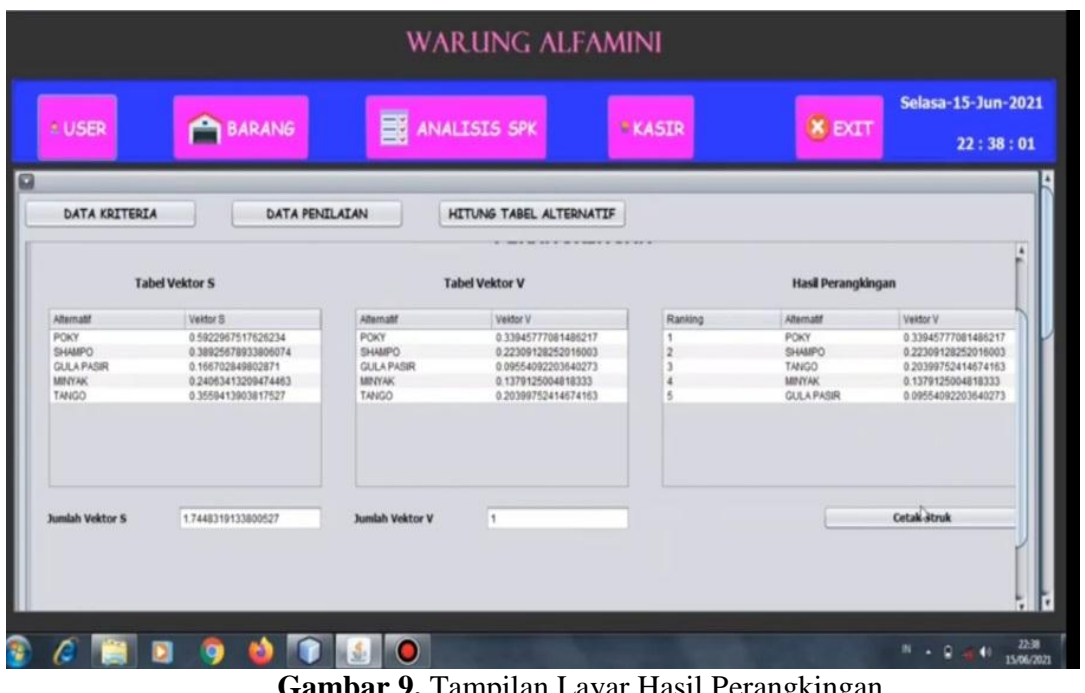

Tampilan layar diatas adalah tampilan layar hasil perangkingan SPK metode Weight Product. Hasil perangkingan ini dapat dicetak dalam bentuk pdf.

\section{SIMPULAN}

Metode Weighted Product (WP) dalam mengimplementasikan sistem pendukung keputusan pemilihan sembako terpopuler saat pandemi Covid-19 berbasiskan java netbeans berhasil memberikan saran pemilihan sembako yang merupakan nilai tertinggi dari perhitungan metode Weighted Product (WP). Adanya aplikasi yang dibuat ini semoga berguna khususnya bagi pemilik toko dan umumnya bagi masyarakat luas dimana saat pandemi Covid-19 ini sering terjadi punic buying yang mengakibatkan kepanikan masyarakat berbondong-bondong membeli sembako secara massal sebagai langkah antisipasi dan persediaan.

\section{DAFTAR PUSTAKA}

[1] dkk Tonni Limbong, Muttaqin, Akbar Iskandar. (2020) Metode Dalam Pengambilan Keputusan. Yayasan kita menulis.

[2] Putra, Nanda Perdana. (2020). Virus Corona Picu Panic buying makanan, masker, hand Sanitizer, bagaimana Meredamnya?

https://www.liputan6.com/news/read/4193886/headline-virus-corona-picu-panic-buying-makananmasker-hand-sanitizer-bagaimana-meredamnya

[3] Jeperson, Hutahaean. (2015). Konsep Sistem Informasi. Yogyakarta: Deepublish Publisher.

[4] Agung, Halim (2016). Aplikasi Sistem Pendukung Keputusan Untuk Pemilihan Siswa Teladan Menggunakan Metode Topsis. Universitas Bunda Mulia. Jakarta: Vol 8 No 02.

[5] Susanto, Fery (2020). Pengenalan Sistem Pendukung Keputusan. Yogyakarta: Deepublish Publisher.

[6] Pratiwi, Heny (2016). Buku Ajar Sistem Pendukung Keputusan. Yogyakarta: Deepublish Publisher.

[7] M. K. Febriana Sari (2018). Metode Dalam Pengambilan Keputusan. Sleman: CV. Budi Utama.

[8] Supriyono, H., \& Sari, C. P. (2015). Rumah Tinggal Menggunakan Metode Weighted Product. Jurnal Ilmu Komputer Dan Informatika Pemilihan, 1(1), 23-28.

[9] Zai, Y., Mesran, \& Buulolo, E. (2017). Sistem Pendukung Keputusan untuk menentukan Buah Rambutan dengan Kualitas Terbaik menggunakan Metode Weighted Product (WP). Media Informatika Budidarma, 1(1), 8-11.

[10] Susliansyah, Ririn Restu Aria, Susi Susilowati. (2019). Sistem Pemilihan Laptop Terbaik Menggunakan Metode Weighted Product. Universitas Bina Sarana Informatika. Vol 16 No 01. 